\title{
SERGIO CAPPELLO, Différences et altérité dans le récit idyllique médiéval, Floire et Blancheflor
}

\section{Maria Colombo Timelli}

\section{(2) OpenEdition}

\section{Journals}

Édition électronique

URL : http://journals.openedition.org/studifrancesi/16167

DOI : $10.4000 /$ studifrancesi. 16167

ISSN : 2427-5856

\section{Éditeur}

Rosenberg \& Sellier

\section{Édition imprimée}

Date de publication : 1 juillet 2019

Pagination : 133

ISSN : 0039-2944

\section{Référence électronique}

Maria Colombo Timelli, « SERGIO CAPPELLO, Différences et altérité dans le récit idyllique médiéval, Floire et Blancheflor», Studi Francesi [En ligne], 187 (LXIII | I) | 2019, mis en ligne le 01 juillet 2019, consulté le 25 janvier 2021. URL : http://journals.openedition.org/studifrancesi/16167 ; DOI : https://doi.org/ 10.4000/studifrancesi. 16167

Ce document a été généré automatiquement le 25 janvier 2021.

\section{(c) $)(1) \Theta$}

Studi Francesi è distribuita con Licenza Creative Commons Attribuzione - Non commerciale - Non opere derivate 4.0 Internazionale. 


\title{
SERGIO CAPPELLO, Différences et altérité dans le récit idyllique médiéval, Floire et Blancheflor
}

\author{
Maria Colombo Timelli
}

\section{RÉFÉRENCE}

SERGIO CAPPELLO, Différences et altérité dans le récit idyllique médiéval, Floire et Blancheflor, «Littératures» 77, 2017, pp. 31-46.

1 Cet article vise à souligner l'originalité du Conte de Floire et Blanchefleur, récit idyllique composé vers le milieu du XII $^{\mathrm{e}}$ siècle, vis-à-vis de la production littéraire contemporaine, tant épique qu'arthurienne, pour ce qui tient à la représentation de l'altérité musulmane. De fait, tous les motifs constitutifs de ce type de récits (subversion de la mésalliance, exclusion, création d'un ordre social nouveau) sont concernés, et même la conversion finale de Floire, qui permet son intégration dans l'Occident chrétien, semble marquée par une vision somme toute équilibrée et optimiste; les interactions entre monde chrétien et monde musulman paraissent donc possibles, ainsi qu'une réconciliation fondée sur l'acceptation des différences sociales et culturelles, alors que l'appartenance religieuse apparaît comme moins pertinente. 